\title{
AN INTRODUCTION: WRITING THE SELF
}

I spend most of my time reading and writing, and often wonder how my identity interacts with my writing. Who am I and why do I write?

My early books were based on a Marxist approach. All the people I admired were Marxists, and it was exciting learning the theory. More importantly, I'd always had the feeling that the world was unfair and unjust, and I so much wanted to do something to make it better.

Now, the strange thing is, retrospectively, that though I saw things from a Marxist perspective, I did not see myself as a black person. This meant, among other things, that I did not seriously analyse issues of 'race'. I remember an evening when I invited a colleague home for supper. After a few hours, she gently commented: 'This is a white man's house'. I was stunned. But it was true; there was not one object or sign which showed that I had come from India, yet I had a high respect for Indian culture and a concern for the exploited peoples of the Third World. I still wonder how and why this aspect of my being had been repressed.

Gradually, my views and attitudes changed. I began to see things according to my commitment to Marxism. I read widely and then wrote a book on anti-racist education. I would argue that my identity changed and I remember that a German friend of mine was not happy with this redefinition. 'You are not black,' she would say, 'you have white culture.'

Could I call myself an Indian intellectual? Well, yes, I was born in India, so I am an Indian intellectual. But my cultural background is almost entirely English. But, because I am not able to identify with Great Britain, the imperialist power, I do not like being called 'Black British'. And 'Indian British' definitely sounds odd, unlike 'Indian American'.

I don't know when I became seriously interested in psychoanalysis. 
I can't give a precise date because, in a sense, I have always been interested in it. I joined a study group, and after some years I wrote a book about Lacan's theories. I learned to interpret films and plays and my own life from a psychoanalytic viewpoint. During this time, I was aware that there had been a general intellectual shift from politics to psychoanalysis. Many friends whom I had first met in a Capital reading group, I met again in Lacanian circles.

Recently, I have felt very saddened by the events in eastern Europe. I am painfully aware that the heroic struggles of men and women at the beginning of the century have been rejected by the younger generation. I had naively thought that books outlived the individuals, but I learned that this is not the case with most authors. I had strongly identified with my writing for a Marxist sociology of education. I felt that my books were a justification of my life. I then learned that my books were unobtainable, that they were all out of print. I felt that these happenings changed my identity.

As I have just said, at one time I thought of myself as a Marxist (I still do); I then became interested in 'race' and later on in Lacanian psychoanalysis. I have not rejected any of my other concerns, but have tried to integrate them. It is often said that one way of finding out about one's identity is to ask: who does one write for? Does one write for one's self ? I don't think so. We are, as Sartre said, always in a situation. I have heard some writers say that they write 'for themselves'. But I do not believe them. Every writer writes for someone. Sometimes I think that I write and keep on writing to gain recognition from ... ; but I can tell you about that later.

\section{PASSPORT PHOTOGRAPHS}

Who am I? Shall I look at my passport to find some clues about my identity? I have three passports, all British, but the first two have had the right-hand top corner clipped and have been stamped 'cancelled'. In the first one, I am a young man with a lot of hair and a confident smile. My height is $5 \mathrm{ft} 8 \mathrm{in}$. and I am a schoolteacher. In my second passport photograph, most of the hair has gone. I have a white beard and a serious expression. My height now is $1.73 \mathrm{~m}$ and I am a college lecturer. In the third, current passport, the smaller red one, I am bald. Again, I have a serious expression, but now my face is heavily lined. My friend asks: which is the real you? Of course, people see me in many different ways: a 'Paki', a 'father figure', 'an old man'. (I've noticed that being old for Asians is not associated with becoming 
more conservative, as it is in the West, but with being more understanding.)

I want to have a closer look at my new red passport, which is in front of me. It is smaller than the old blue one; on the cover, at the top, are the words 'European Community' and underneath is written 'United Kingdom of Great Britain and Northern Ireland'. On the back of the inside cover are my names, my nationality and my date and place of birth. The inside of the passport contains visa stamps which permitted me to stay in India and Pakistan for a certain number of days. The Indian visa states that it is not valid for restricted or protected areas; these visas permit entry to and through defined territories.

The passport refers to my nationality (British citizen). I think of it as a formal category because it does not express how I feel about it. I am not proud to be 'British'; it reminds me of the scars of imperialism, the days of the Raj. I feel more sympathetic to the idea of being a citizen of the European Community, but here too I feel ambivalent: I would rather be a citizen of a federal European Community, but friends remind me that the concept of 'Fortress Europe' is a Eurocentric strategy to maintain the power and the privilege of the 'First World'.

What a passport does is to show you who you are so that you can be recognised in a bureaucratic sense. But of course, you are more than a photograph plus a few statements about yourself. Even if a passport is supposed to be proof of your nationality, it says nothing about you as a person. I want to suggest that identity is to do with more than one's passport, more than one's appearance; that it is to do with who one thinks one is, what one believes and what one does. Some would say that to get to know someone's identity you have to talk to them, to find out about how they think and feel about themselves.

There exist many theories that inform us that identity is determined. They include socialisation (role theory), ideology (the state apparatuses that Althusser describes), discourse theory (the early Foucault), discipline and the technologies of the self (the later Foucault). In all three theories, institutions play a crucial determining role: there is the family, the school, the place of work and, increasingly, the media. There is no doubt that identity-construction is increasingly dependent on images. Other factors which we must consider include how what is here called 'commodity aesthetics' determines the direction that an individual's being takes. Commodity aesthetics is largely 
aesthetics based on our perception of the body, and on processes of sexualisation. I want to stress that our identities are not entirely determined: there are counter-identifications at work as well.

I want to argue that we do not have a homogeneous identity but that instead we have several contradictory selves. Moreover, I believe that two important features of the human subject are perpetual mobility and incompletion. I have been told that, for many young black Americans, Malcolm X is an example of someone who was constantly striving to change himself. In the face of great adversity, he refused to acquiesce or compromise, and became the voice of militant opposition. In a sense, identity is a process; it is heterogeneous.

But now let's begin. I want to focus on three key ideas: the meaning of home, the journey of the migrant and the crossing of the border. 